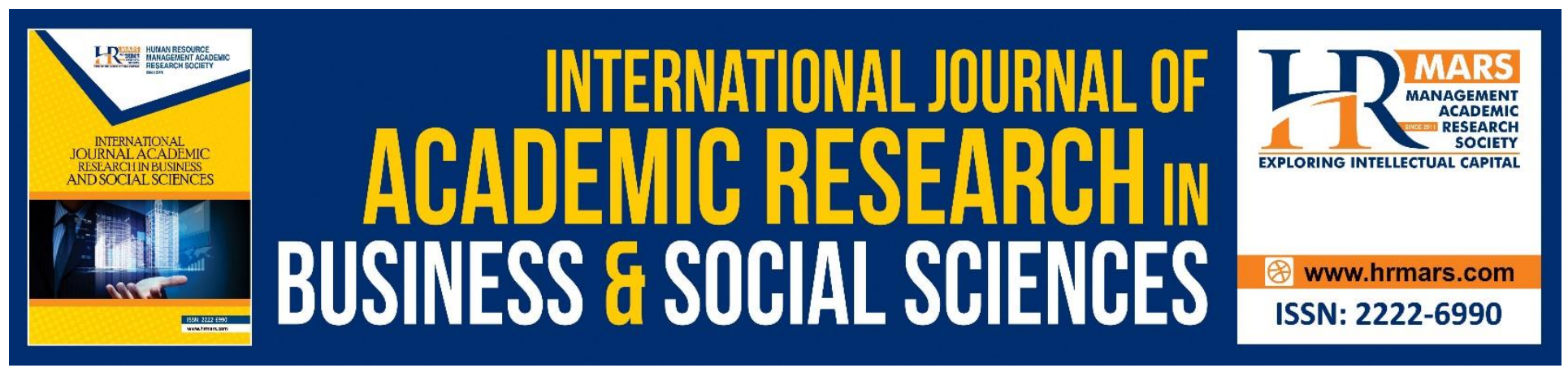

\title{
Female Circumcision between View of Islamic Scholars and Medical Experts
}

\section{Basri Ibrahim, Firdaus Khairi, Jazlan Mat Jusoh}

To Link this Article: http://dx.doi.org/10.6007/IJARBSS/v8-i10/4752

DOI: $10.6007 /$ IJARBSS/v8-i10/4752

Received: 17 Sept 2018, Revised: 24 Oct 2018, Accepted: 29 Oct 2018

Published Online: 31 October 2018

In-Text Citation: (Ibrahim, Khairi, \& Jusoh, 2018)

To Cite this Article: Ibrahim, B., Khairi, F., \& Jusoh, J. M. (2018). Female Circumcision between View of Islamic Scholars and Medical Experts. International Journal of Academic Research in Business and Social Sciences, 8(10), 509-523.

\section{Copyright: (C) 2018 The Author(s)}

Published by Human Resource Management Academic Research Society (www.hrmars.com)

This article is published under the Creative Commons Attribution (CC BY 4.0) license. Anyone may reproduce, distribute, translate and create derivative works of this article (for both commercial and non-commercial purposes), subject to full attribution to the original publication and authors. The full terms of this license may be seen at: http://creativecommons.org/licences/by/4.0/legalcode

\section{Vol. 8, No. 10, 2018, Pg. 509 - 523}

Full Terms \& Conditions of access and use can be found at http://hrmars.com/index.php/pages/detail/publication-ethics 


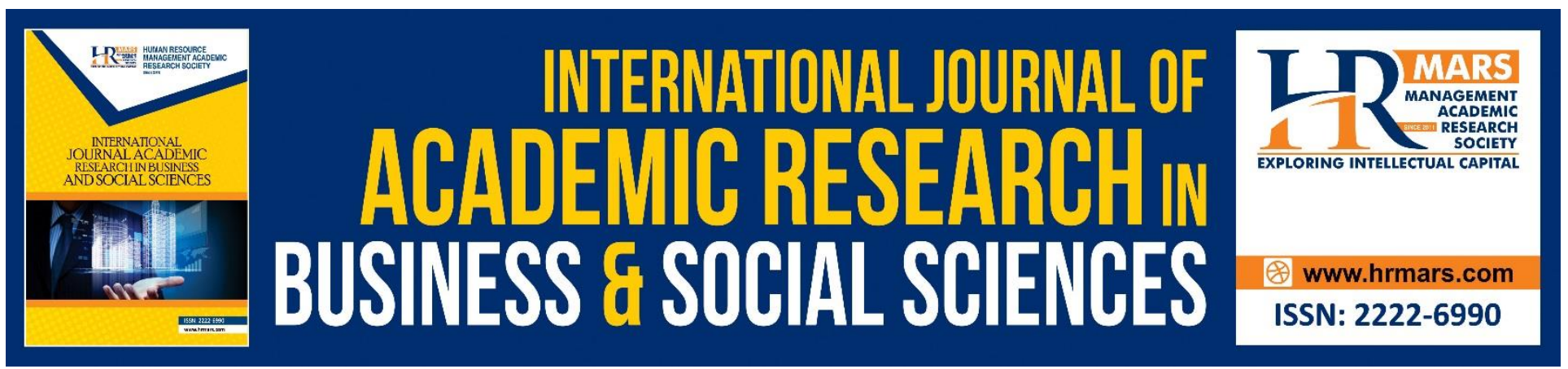

\title{
Female Circumcision between View of Islamic Scholars and Medical Experts
}

\author{
Basri Ibrahim ${ }^{1}$, Firdaus Khairi², Jazlan Mat Jusoh ${ }^{3}$ \\ ${ }^{1}$ Global Wisdom Academy, Universiti Islam Malaysia, Cyberjaya, Malaysia. \\ ${ }^{2}$ Center for Fundamental And Liberal Education, Universiti Malaysia Terengganu, Malaysia. \\ ${ }^{3}$ Faculty of Islamic Contemporary Studies, Universiti Sultan Zainal Abidin, Terengganu, Malaysia. \\ Corresponding Author: drbasr67@gmail.com
}

\begin{abstract}
Circumcision is one of the practices in sharia (laws) of Islam and it is practiced by Muslims since years ago. It is done to the male and also female individual. For male, it is obligatory (wajib) according to majority of scholars, but for female the scholars contradict each other on its status whether it is obligatory, recommended (sunat) or neutral (makramah/harus). The purpose of this study is to discuss on the opinions of Islamic scholars about female circumcision and the evidences that they use to find a more suitable opinion with the need (maslahah) of Muslim women nowadays and to see the extent of its relationship with medical field, besides to the extent of its practice among women in Malaysia in accordance to the view of Syafi'is school of thought which is the belief of Muslims in Malaysia. The methodology used in this writing was based on qualitative study. Data were collected through library study by referring to books related to tafsir (interpretation of Qur'an), sunnah (Prophet's traditions), classical books of Islamic jurisprudence, contemporary Islamic jurisprudence, encyclopedia of medical Islamic jurisprudence and views of Islamic scholars and today's medical experts. This study found that the suitable opinion to be implemented to female circumcision nowadays is that it is neutral only in Islamic law and not obligatory, due to ambiguity of proposed evidences from many aspects, while the procedures of circumcision should be referred to medical experts. The practice of circumcision among women in Malaysia does not conform to the view of scholars from Syafi'is school of thought and also does not involve with the prohibition published by WHO.
\end{abstract}

Keywords: Circumcision, Syafi'is school of thought, Islamic jurisprudence, maslahah (need), makramah (neutral). 
INTERNATIONAL JOURNAL OF ACADEMIC RESEARCH IN BUSINESS AND SOCIAL SCIENCES

Vol. 8, No. 10, Oct. 2018, E-ISSN: 2222-6990 ㄷ 2018 HRMARS

\section{Introduction}

Circumcision is already recognized in Islam and Muslim community. It is done to male and also female individual. Circumcision is one of nature practices which are mentioned in hadis sahih (authentic hadis). In a hadis narrated by Abu Hurairah R.A explaining that he heard Prophet p.b.u.h. said:

Means: Five practices are among sunnah fitrah (tradition of nature) which are circumcision, istihdad (shaving pubic hair), removing armpit hair, cutting nails and shaving moustache.

(Sahih: al-Bukhari:5441)

In other hadis narrated by Ammar bin Yasir r.a explaining, Rasulullah p.b.u.h. said:

Means: Among the practice of nature (sunnah fitrah) are gargling, istinsyaq (inhaling water into the nose), shaving moustache, cutting nails, removing armpit hair, shaving pubic hair, washing the joints of hand, cleaning (sprinkling water to the private part after ablution) and circumcision.

(Sahih: Majah: 294)

The meaning of nature is that, the practitioner is attributed to the nature which Allah has determined on His servants of the practice, and He encourages it for the sake of perfection of their attributes. Basically, the attributes do not need the commandments of Islamic laws in the practice, as the practice is preferred and suitable with human nature (https://almanhaj.or.id,2018)

According to al-Qayyim r.h (1971), nature is divided into two categories. First, the nature related to the heart and it is the introduction and knowing of Allah s.w.t, loving and prioritising Him from others. Second, the practical nature involving the practices stated above. the first one purifies the soul and cleans the heart, while the second one purifies the body. Both are assisting and strengthening each other. The core of body's nature is circumcision.

An arising question is that, is the circumcision obligatory as understood by some of Malay community and does the circumcision performed to the female fulfil the meanings enquired by scholars of Syafi' is school of thought? What is the opinion of medical experts regarding the female circumcision issue and how to standardise between the opinion of scholars and medical experts on the female circumcision? To answer the question, this article is brought forward to discuss the view of Islamic scholars and medical practitioners on the female circumcision issue and evidences used by scholars to oblige the female circumcision, to see the strength degree of the evidences used as the basis, qualifying it to be obligatory and its relationship with the view of medical experts. It is also aiming to observe the circumcision practice in Malaysia and its compatibility with the view of alsyafi' $i$ scholars, obliging the circumcision to the female.

A lot of writings on circumcision have been done such as Pemikiran Husein Muhammad Tentang Khitan by Nelli (2015), Khitan Perempuan Perspektif Hadis Dan Sirkumsisi Menurut WHO 
by Muhamad Sauki (2010), Khitan al-Inath by al-Qaradawi (2007), al-Mawsu'ah al-Fiqhiyyah alTibbiyah by Kan'an (2000), Perubatan Moden Menurut Perspektif Islam by Ibrahim, B, which also discussed the male and female circumcision issue in one of his writings which is, al-Fiqh al-Islami Fi Tariq al-Tajdid by al-'Iwwa (1998), that touched on the female circumcision in one the issues featured and others. But the discussion and explanation of the female circumcision according to Islamic scholars and medical are rarely found. Due to that, a study should be done to view the issue more closely in choosing the more suitable opinion with the reality and need of Muslim female nowadays.

\section{Research Methodology}

This writing was based on qualitative study. Data were collected from library study by referring to books related to tafsir (interpretation of Qur'an), sunnah (Prophet's traditions), classical books of Islamic jurisprudence, contemporary Islamic jurisprudence, encyclopaedia of medical Islamic jurisprudence and views of Islamic scholars and today's medical experts. The data collected were then analysed and explained using comparison method to gain results in accordance with the determined objectives of study.

\section{Findings}

Circumcision was initiated by the teachings Prophet Abraham a.s, while there was nobody who had performed circumcision before that (al-'Arabi, 2003.1:36). In a hadis narrated by Abu Hurairah r.a explaining that Prophet p.b.u.h. said:

Means: Abraham circumcised after he turned eighty years old and he circumcised in alQaddum.

(Sahih: al-Bukhari:3107)

After Prophet Abraham a.s, tradition and practice of circumcision continued to all Prophets and their followers, until al-Masih. Prophet Isa a.s also circumcised. Christians admit and do not deny the circumcision, as they admit the prohibition of eating pork and income of Saturday (al-Qayyim, 1971).

Being a teaching of Prophet Abraham a.s., circumcision is one of Allah's commandments upon Prophet Abraham to be fulfilled, mentioned as "kalimat"(words) which means commandment and prohibition. Prophet Abraham a.s fulfilled the commandment perfectly, until he was chosen by Allah s.w.t as a role model and leader of the universe. In surah al-Baqarah, Allah s.w.t said:

Means: "And (remember), while Abraham was being tested by his God with several words (commandments and prohibitions), and Abraham fulfilled them. Allah said: "Truly I will make you the leader for all mankind". Abraham said: "(And I also request) from my descendants". Allah said: "My promise (of this) will not reach the unjust". (al-Baqarah 2: 124) 
INTERNATIONAL JOURNAL OF ACADEMIC RESEARCH IN BUSINESS AND SOCIAL SCIENCES

Vol. 8, No. 10, Oct. 2018, E-ISSN: 2222-6990 ㄷ 2018 HRMARS

\section{Benefits of Circumcision}

Circumcision has many benefits which are:

a. Becomes one of Allah's commandments which is commanded to His servants. It functions to improve the physical and spiritual beauty of human and to perfect the straight path of the Prophets' father, ancestor of Ismail and Ishaq's descendants which is Prophet Abraham a.s. Circumcision is a dipping and and sign of Allah s.w.t towards His servants. Allah SWT said:

Means: Allah's dipping. And whose dipping is better than Allah's?

(al-Baqarah 2:138).

b. The marking of submission to Allah s.w.t as in the past time when a marking was put onto the ear or body of a slave to indicate their slavery to the master. If the slave ran away from the master, he would be returned to his master guided by the marking. A person who circumcises by cutting the skin at the private part, means that he has submitted himself to Allah s.w.t that everyone else will know the fact that the person who circumcises is a servant of Allah s.w.t.

c. A sign of purity, cleanliness and ornament for His decent servant (al-Qayyim, 1971:46-49).

d. Neutralise the sexual desire. If a person is not circumcised, he would resemble animal behaviour. If it is cut entirely, he will become like a dead object with no desire. Therefore, uncircumcised person, either male or female, will not be satisfied during the intercourse (hypersex). On the other hand, a mistake in female circumcision, will lead to sexual frigidity towards the man.

e. Brighten the face and satisfy the couple. In a hadis narrated from Ummu 'Atiyyah al-Ansari explaining:

Means: A woman in Madinah worked as a circumciser. Prophet p.b.u.h. said to her: Do not remove all. Truly, it will benefit the woman and make her loved more by the husband.

(Hasan: Dawud: 5271)

f. To drive away Satan from dirty places, such as at the uncircumcised skin (https://almanhaj.or.id, 2018).

\section{Definition of Circumcision}

Male circumcision is the removal of the foreskin which covers the glans of penis to expose the glans (balanus). While female circumcision is the cutting of a piece of skin shaped like a cock's spur located above the urethral orifice (al-Zuhaili, 2007). 
INTERNATIONAL JOURNAL OF ACADEMIC RESEARCH IN BUSINESS AND SOCIAL SCIENCES Vol. 8, No. 10, Oct. 2018, E-ISSN: 2222-6990 ㄷ 2018 HRMARS

According to Kan'an (2000), a medical expert in Saudi Arabia, female circumcision means cutting a small part of clitoris which is a small reproductive organ located on upper part of female genital. It has a function related to sexual stimulation and pleasure feeling during sexual intercourse. Its function resembles the function of male genital.

\section{Proofs of Circumcision}

There are many proofs explaining the law binding of circumcision in Islam, in which among of them are:

a. Allah s.w.t said:

Means: Then We revealed to you (Muhammad): "Follow the religion of Abraham, a decent person" and he is not one of the polytheists

(al-Nahl 16:123)

Circumcision means following the religion of Prophet Abraham a.s.

b. Hadis narrated from Abu Hurairah r.a, explaining:

Means: Nature is five which are circumcision, shaving pubic hair, removing armpit hair, (Sahih: al-Bukhari:5439) cutting nail, and cutting moustache.

c. Hadis narrated from 'Uthaim bin Kulaib from his father from his grandfather, explaining that Prophet p.b.u.h. said:

Means: Vanish from you the hair of kufr (disobedience, the sign of disobedient people) and circumcise.

(Hasan: Dawud:302)

d. Hadis narrated from ibn Abbas r.a, Prophet p.b.u.h. said:

Means: Circumcision is a tradition for male and an honour for female. (Da'if: al-Baihaqi:17343)

e. Hadis narrated from Ummu 'Atiyyah al-Ansari explaining:

Means: A woman in Madinah worked as a circumciser. Prophet p.b.u.h. said to her: Do not remove all. Truly, it will benefit the woman and make her loved more by the husband.

(Hasan: Dawud: 5271)

f. Hadis narrated from Abu Musa al-Asy'ari r.a, Prophet p.b.u.h. said: 
INTERNATIONAL JOURNAL OF ACADEMIC RESEARCH IN BUSINESS AND SOCIAL SCIENCES

Vol. 8, No. 10, Oct. 2018, E-ISSN: 2222-6990 (C) 2018 HRMARS

Means: When a man is between four limbs of woman (having sex with woman) and the circumcised part meets the circumcised part, the bath is obligatory.

(Sahih: Muslim:526)

These hadis explain that when a sexual intercourse happens, there must be a meeting of male and female circumcised parts, which proves that woman should also circumcises as man.

\section{Forms of Female Circumcision}

Female circumcision involves three forms which are:

a. Simple circumcision which is the removal of a part of clitoris or the entire clitoris..

b. Moderate circumcision which is the removal of clitoris and two inner lips of vagina (labium minus Pudendi) together with some of two outer lips of vagina (Labium Majus Pudendi). The lips part is the flesh surrounding the vaginal orifice. They have certain functions during the sexual intercourse.

c. Intensive circumcision, involving the removal of clitoris, labium minus pudendi dan labium majus pudendi. This will mutilate the appearance of female private part completely. This type of circumcision is known as circumcision of pharaoh (khitan fira'uni), as it was practised in the era of pharaoh the governor of Mesir, especially during era of Ramses. It happened 1000 years before Christ (Kan`an, 2000).

In this type of circumcision, a small stick with hole is put at the opening of female labium majus pudendi after circumcision. After the bleeding stops, the small hole will remain there to allow the excretion of urine. After circumcision also, both legs of the girl will be bound for 40 days to make sure that the injury has recovered and there will be no other opening appearing besides the opening at the private part only (Kan'an, 2000).

\section{Female Circumcision According To Islamic Scholars}

If it is examined carefully, there are four views among the four sects and even in other sects regarding the female circumcision which are:

a. Circumcision is obligatory to female. This is the view of al-Syafi' $i$, Hanbali sect and the view of choice of Syeikhul Islam Taimiyyah (1414H). Imam al-Nawawi (t.th, 1) for example opined that circumcision is obligatory for both male and female. It is the opinion of majority among salaf (old school of thought) figures, as explained by al-Khattabi. Among those who obliged it was imam Ahmad. Indeed, he was an authentic and famous sect proved cited by imam al-Syafi'i and hold by most of the scholars.

b. Circumscision is encouraged for female. It is a belief hold by al-Hasan al-Basri, scholars of Hanafi sect, Imam Malik and a narration from imam Ahmad, as stated by al-Kalbi in al- 
Qawanin al-Fiqhiyyah (2013,). According to imam al-Nawawi (t.th) Imam Malik, and Abu Hanifah, believed that circumcision is encouraged for Muslims either male or female. Indeed, according to al-Rafi'i, it is a view in Syafi'is school of thought. Another opinion explains that circumcision is obligatory to male and an honour to female.

c. Circumcision is an honour to female (below an encouragement and more to neutral). It is the third opinion of imam Ahmad. It is also believed by most of Maliki scholars such as Sahnun. This view was also chosen by Qudamah (1997).

\section{Circumcision According To Medical Expert}

Circumcision is not an obligation to the female according to medical field. Doctor Kan'an, (2000), a medical expert in middle East stated that female circumcision should only be retained in specific situation confirmed only by related medical expert. For example, in case of when the female clitoris is too long and complicate the process of sexual intercourse. The need of circumcision at this situation is not due to sharia commandment. Instead, it serves as an essential operation, same as other operations done on the human body to remove excess organs from the body, in which its existence may harm the human.

Clitoris for the woman plays an important role in reaching the orgasm or excitement in intercourse. This is due to the existence of sensitive cells at the clitoris, which increase the libido in sexual intercourse, resembling the erection of male penis during sexual stimulation. Clitoris also undergoes stimulation and erection at the first and second level of intercourse until its length doubles from the normal length. A woman will not attain the second level except with the contact at the clitoris. The more frequent a contact happens at the clitoris, the more frequent the stimulation happens. From here, a woman will experience an extreme excitement.

By performing circumcision at the clitoris, it will prevent the woman from experiencing the sexual stimulation and excitement during the intercourse, in fact it may lead to sexual frigidity to the woman and at the same time causing the woman to refuse sex with the husband. This will deteriorate the marital condition and relationship with the husband. When labium minus pudendi and labium majus pudendi are removed, it leads to a bigger harm, besides eradicating the excitement during intercourse completely and switching off sexual stimulation (Kan'an,2000).

\section{Analysis of Proofs for Circumcision}

If it is observed from proof in al-Qur'an, there would be no clear statement on the needof circumcision for the woman, neither in Makkiyah nor Madaniyyah surahs. However, majority of scholars from Syafi'is school of thought believe that female circumcision is obligatory according to proof from verse 123 surah al-Nahl:

Means: Then we revealed to you (O Muhammad) to follow the religion of Abraham, inclining toward truth; and he was not of those who associate with Allah.

(al-Nahl 16:123) 
They state that circumcision is included into the traditions of Prophet Abraham a.s., as stated in the authentic hadis previously, explaining that Prophet Abraham a.s. did circumcision at the age of 80 years in Qaddum.

According to al-Qaradawi (2007), using the above verse as the proof to oblige circumcision to female is considered as burdening with something unneeded. This is because following the traditions of Prophet Abraham a.s. is more than just merely following the tradition of circumcision. Indeed, the real meaning of following Prophet Abraham a.s. as in the verse is by following his path of upholding tauhid (oneness of God), avoiding taghut (diversion of worship), preaching people to the religion of Allah s.w.t with wisdom and evidence, as the one happening during the preaching of Prophet Abraham a.s. to his people. Allah s.w.t said:

Means: Truly with you are the bringing of Prophet Abraham a.s. and his followers good example, as they said to his people (the disobedient): "Truly we ** from you and what you worship besides Allah; we disobey (all worship of) yours and (by this) it exposes your hostility and hatred between us and you forever, until you worship Allah only", but do not make example of Prophet Abraham's words to his father (saying): "I will pray to my God to forgive your sins, and I have no strength of holding (torments) from Allah at all from falling onto you". (And do pray $O$ you who believe as Prophet Abraham and his followers prayed while they were having hostility towards the disobedient people, saying): "O our God! to You only we submit ourselves, and to You only we repent, and to You only the returning place!.

(al-Mumtahanah 60:4)

If it is used as a proof to oblige the female circumcision, it can only be used for male and not for female (al-Qaradawi,2007).

Relating to the hadis, it is gladly informed that it has been agreed by all scholars either among scholars of hadis, Islamic jurisprudence or principles of jurisprudence that weak hadis cannot be made a reference in the matter of Islamic law. Some scholars take a more lenient approach in proving with weak hadis in the matter of encouragement of worship and others. On the other hand, in matter regarding laws of permission and prohibition (halal dan haram), obligation and encouragement (wajib and sunat), i cannot be based on weak hadis. Among the hadis used as proof in the matter of female circumcision is a hadis by $A^{\prime}$ isyah r.a, Rasulullah p.b.u.h. said:

Means: When two circumcised parts meet, the bath is obligatory.

(Sahih: al-Tirmizi:102)

The above hadis explains why circumcision happens among Arabic women in the time of Rasulullah p.b.u.h. and it is not argued, indeed it has become their life custom. The arising question is that its law is obligatory or encouraged (al-Qaradawi, 2007). The matter is not mentioned clearly. 
INTERNATIONAL JOURNAL OF ACADEMIC RESEARCH IN BUSINESS AND SOCIAL SCIENCES

Vol. 8, No. 10, Oct. 2018, E-ISSN: 2222-6990 ㄷ 2018 HRMARS

When it is not mentioned clearly, according to jurisprudence method, it states that: the origin of each law is neutral except there is a proof of its prohibition.

Regarding the hadis narrated by Ummu 'Atiyyah al-Ansari explaining:

Means: A woman in Medina worked as a circumciser. Prophet p.b.u.h. said to her: Do not remove all. Truly, it will benefit the woman and make her loved more by the husband.

(Hasan: Dawud: 5271)

Abu Dawud himself explained that one of the narrators named Muhammad bin Hasan is not known and the above hadis for him is a weak hadis. Some hadis scholars said that one of its narrators is Muhammad bin Said, but Muhammad bin Said is famous of fabricating hadis, indeed he had fabricated 4000 hadis to confuse Muslims. Khalifah al-Mansur had decided to execute him for his fabrication.

It is not denied that the above hadis was also narrated through other chains of narration, but all are weak, although Syeikh al-Albani validates it to be authentic. There is something doubted which is if the female circumcision is done by every family in Medina, the question is that why it is narrated through weak narrations (al-Qaradawi,2007).

According to al-Azim Abadi (1968), the commentator of book of sunan Abi Dawud, hadis on female circumcision was narrated through many chains. All of them are weak, deformed and problematic. Debating by it is not valid.

If the hadis is accepted as authentic as said by al-Albani, the arising question is that does it lead to an obligation, encouragement or just mere guidance and education? What obvious is that the statement in the hadis is more to an education and guidance only and not indicating the obligatory (wajib) or encouraged (sunat) law of female circumcision. Because it is related to worldly matter and fulfilment of human life's needs. The confession made by the female circumciser showed that the law of female circumcision is neutral (harus) only and the matter is not rejected (alQaradawi, 2007).

Regarding hadis narrated by ibn Abbas r.a, Prophet p.b.u.h. said:

Means: Circumcision is a tradition for male and an honour for female.

(Da'if: al-Baihaqi:17343)

The commentator of this hadis evaluated it as a weak hadis. The above hadis was narrated by al-Baihaqi in al-Sunan (1344H) and al-Tabrani in al-Mu'jam al-Kabir (1983), involving weak chain 
of narration. In fact, even al-Albani himself evaluated the above hadis as weak in his Silsilah alAhadith al-Da'ifah (1992).

Even if the hadis is authentic, it still does not prove that circumcision is obligatory or encouraged, instead it proves that circumcision is a good practice from cultural (uruf) aspect and at the same time there is no authentic and agreed proof saying that circumcision is obligatory or encouraged for female. Makramah (neutral law) is something that can change. Something considered as neutral in a certain country or at a certain time, might be considered as not in other country or at other time. That is way some Islamic countries in which most of its women are not circumcised, such as the gulf countries and northern Africa. That also explains why many of medical experts nowadays who do not agree with female circumcision, on basis of view that it is an intrusion to woman's body (al-Qaradawi, 2007).

Related to the qiyas (analogy) proof which resembles the obligation of circumcision to male to the female, on the basis of sharia commandment which is usually directed towards both male and female. Indeed, a hadis explains that:

Means: Truly, woman is the relative of man.

(Sahih:Ahmad:26195)

It is gladly informed that analogy has pillars and conditions which are obligatory to be fulfilled, such as existence of 'ilah (cause) which is shared by the analogised subject (maqis) or branching matter with the subject of analogy (maqis 'alaihi) or basic matter.

Among them is that there is no difference between the branching matter and basic matter. If not, the analogy done will be rejected and also called as Qiyas Ma'a al-Fariq. What obvious is that there is a clear difference between male and female, in which circumcision is definitely beneficial to the man but it causes harm to the woman.

Among them also is that basically, changing the creation of Allah SWT is prohibited and forbidden. This includes cutting of a small part of the organ in human body. However, it is excused in the male circumcision as it is validated by an authentic proof. Matters other than that will remain in the prohibition and forbidding. This conforms to the method of principles saying that "something appearing in the form of exception is guarded and nothing can be analogised to it" (al-Qaradawi, 2007):

Related to the proof and reason given by certain people saying that circumcision is good for female as it will control the female libido which is stronger than the male's and there is a hadis mentioning that, to answer it, it is gladly informed that the claim of the existence of hadis saying is actually a fabricated hadis. Besides that, the circumcised part of female will not be stimulated except by direct contact and it will not happen just by jostling in a place such especially in a public transport. 
Moreover, man and woman who guard his or her dignity carefully will feel ashamed of the contact happening during the jostling, even though it happens accidentally and unintentionally.

Man and woman both are encouraged to guard their dignity and avoid crowded places and encounter between man and woman. However, to solve the problem above is not by circumcising female (al-'Iwwa,1998:).

Besides that, there is no proof from agreement of scholars (ijmak) regarding the claim that female circumcision is a must. There are scholars who believe that circumcision for female is obligatory, some believe that it is encouraged and some also opine that is is recommended. And even some of the scholars believe that the law for female circumcision is honoured (makramah).

Nevertheless, we can go out of those opinion by saying that the scholars agree that the law of female circumcision is not more than just neutral. Neutral is not obligatory and not encouraged. Holding to the scholar's opinion stating that the law of female circumcision is honoured (makramah) approaches the neutral (harus) law. Honoured means something that is considered good by the culture (uruf). People who believe in it means that they believe in the view that judges female circumcision as neutral only (al-Qaradawi, 2007).

The conclusion is that there is nobody among scholars which think that not circumcising falls into the law of prohibition, makruh tahrim (dislike for prohibiting) or tanzih (dislike for purfying). This conclusively indicates that the law of it is just neutral. This also shows the existence of ijmak dimni from all sects and paths of jurisprudence which exist in Muslim community on the neutral law. Therefore, people who want to perform circumcision to the daughter by getting the service from female circumciser and not going beyond the line, are not wrong, as they do not perform a forbidden action. It is improper to insult people who want to perform it and naming the practice as inhumane crime done in the $21^{\text {st }}$ century.

\section{Conditions of Female Circumcision}

Among them are:

a. Cannot go over limit in cutting the circumcised part asit prohibits the woman from experiencing the pleasure in sexual intercourse allowed by Islam which is known as khitan fir'auni (circumcision of pharaoh).

b. The circumcision must be done by a female expert and known for her expertise. If not, it can be performed by a Muslim male doctor to consider the emergency condition.

c. Equioments used must be in good condition, suitable and involves appropriate place such as hospital, clinic, health centre and others. Cannot use old equipments and involving inappropriate place ( al-Qaradawi, 2007). 


\section{Female Circumcision in Malaysia}

Circumcision or Female Genital Mutilation (FGM) as pictured by WHO is not same as circumcision practice in Islamic Malay world around Malay Archipelago. There is no specific standard method of circumcision recorded.

Female circumcision which is described by WHO has long been discarded from practice of tradition in Malaysia country. The tradition is by a little cut at the clitoris (kelentit) using a needle or a special knife. It is done a simple way without the excision of the whole clitoris, excision of labia minora or infibulation of labia majora as practised by the tradition African Arabic. Their circumcision practice is too excessive and rising phobia among the girls. The technique is prohibited to be practised in Malaysia.

A cross-sectional study done by Dr Khatijah upon the private medical practitioner throughout Terengganu found that $56.2 \%$ of them provide circumcision service for female infant in their clinics. From the amount, only $31.2 \%$ believe that female circumcision is obligatory. It is quite contrary to the belief of Syafie sect in Malaysia. Regarding the method of circumcision, the brief study found that $55.6 \%(n=15)$ among them only make a small cut at the (lukisan 1$), 25.9 \%(n=7)$; some of them puncture the clitoris using a sterile needle (lukisan 2 ) and $18.5 \%(n=5)$ cut a piece of the clitoris using a needle or a sterile knife (lukisan 3). There is nobody who use the method as described by WHO. They might apply method IV according to WHO category by they do not exaggerate and harm the baby. Majority (62.9\%) of the respondents learnt the technique from senior colleagues and gynaecologist (Suhazli.com.5.1.2018)

\section{Conclusion}

Based on the discussion and explanation above on the circumcision between opinions of Islamic scholars and medical experts, the author is more prone to the scholars' opinion believing that female circumcision is honoured (makramah) and neutral (harus) only and it conforms to the third opinion of imam Ahmad and most of scholars from Maliki sect such as Sahnun. This view is also chosen by Qudamah. It is also aligned with the view of medical experts and several contemporary scholars such as al-Qaradawi and Salim al-'Iwwa. This is because the proofs featured by the party who believe that circumcision is obligatory, is not strong and still can be argued.

To perform the female circumcision, one must refer to the studies and researches by medical experts with moderate view and not of them who follow their lust. If it is proven that circumcision to the female can cause major harm, it should be halted for a moment to prevent accusation. It is alright to differ from the view of past people in female circumcision, as their time is not as sophisticated as nowadays. Moreover, fatwa (announcement of decided law) can change through time, place and situation.

If it is proven that there is a need of circumcision for certain women in alignment with the examination done by medical experts, it can be performed to fulfil the need of involving women and prevent harm from them (al-Qaradawi,2007). 
Nowadays, there are some scholars who call for an action from the authorities on the person who performs the circumcision of pharaoh, as the practice requires the practitioner to pay fine and compensation to the victim, as the woman involved has lost a pleasure in the intercourse, as the pleasure is the right to be respected.

With that, according to Kan'an (2000), female circumcision should be retained in certain situations which are approved by the responsible medical experts only. For example, in the situation where a women's clitoris is too long and complicating the intercourse. Circumcision nowadays is relevant not on the basis of commandment by the religion, but as a needed operation, same as other operations performed on human's body to remove excess organs, as they might harm the person.

The study done by the medical expert in Malaysia found that circumcision done on the woman does not fulfil the view of Syafi'is school of thought at all in which it states that female circumcision is by removing a little of the clitoris. Despite, what is happening is that the medical experts are just injuring the clitoris a little by a needle or a special knife. It is done briefly without the removal of the whole clitoris, the excision of labia minora or infibulation of labia majora as done by certain traditions of African Arabic.

\section{Corresponding Author}

Basri Ibrahim, Jamalullail Professorial Chair, Global Wisdom Academy, Universiti Islam Malaysia, Cyberjaya, Malaysia.

Email: drbasr67@gmail.com.

\section{Acknowledgement}

Special thanks to the GWA, Universiti Islam Malaysia, Cyberjaya for funding the research.

\section{References}

Al-Albani, M.N. (1992). Silsilah al-Ahadith al-Da'ifah Wa al-Mawdu'ah. Al-Riyad: Dar al-Ma'arif. Al-Abadi, S.H.A (1968). 'Aun al-Ma'bud Syarah Sunan Abi Dawud. Al-Madinah al-Munawwarah: alMaktabah al-Salafiyyah.

Al-‘Arabi, A.b.A.I. (2003). Ahkam al-Qur'an. Vol.1. Beirut: Dar al-Kutub al-'llmiyyah.

Al-Baihaqi, A.M.H. (1344H). Al-Sunan al-Kubra. Haidarab: Majlis Da'irah al-Ma'arif al-Nizamiyyah.

Al-Bukhari, M.I. (1422H). Sahih al-Bukhari. Dar Tawq al-Najah.

Dawud, S.A.I.A. (n.d). Sunan Abi Dawud.vol.14. http://www.al-islam.com.

Ibrahim, B. (1999). Perubatan Moden Menurut Perspektif Islam. Kuala Lumpur: Darul Nukman.

Al-'Iwwa, M.S. (1998). al-Fiqh al-Islami Fi Tariq al-Tajdid. Beirut: al-Maktab al-Islami.

Al-Kalbi, M.A.J.G. (2013). al-Qawanin al-Fiqhiyyah Fi Talkhis Mazhab al-Malikiyyah, Tahqiq: Majid alHamawi. Beirut: Lubnan.

Kan'an, M. (2000). al-Mawsu'ah al-Fiqhiyyah al-Tibbiyyah. Beirut: Dar al-Nafa'is.

Majah, A.M.Y.I (2004). Sunan Ibn Majah. Dar al-Risalah al-'Alamiyyah.

Muslim, H. (n.d). Sahih Muslim. Beirut: Dar Ihya' al-Turath al-'Arabi.

Al-Nawawi, A.Z.M.S. (n.d). Majmu' Syarah al-Muhazzab. Beirut: Dar al-Fikr. 
Al-Qaradawi, Y.(2007). Khitan al-Inath. Egypt: Maktabah al-Wabah.

Al-Qayyim, S.A.A.I (1971). Tuhfah al-Maudud Fi Ahkam al-Maulud. Damsyik: Maktabah Dar al-Bayan. Qudamah, M.M.I(1997). al-Mughni.Tahqiq: Abdullah bin Abd al-Muhsin al-Turki. vol.1. Dar 'Alam alKutub.

Al-Tabrani, S.A.Ayyub. (1983). Al-Mu'jam al-Kabir, al-Mausul: Maktabah al-'Ulum Wa al-Hikam.

Taimiyyah, A.T.D.I (1414H). Majmu al- Fatawa, Jam‘ Wa Tartib Abd al-Rahman bin Qasim. Makkah al-Mukaramah: Maktabah al-Nahdah al-Hadithah.

Sauki, M.(2010). Khitan Perempuan Perspektif Hadis Dan Sirkumsisi Perempuan Menurut WHO, Jakarta: Fakultas Usuludin Dan Fialsafat, Universitas Islam Negeri Syarif Hidayatullah.

Al-Zuhaili, M. (2007). al-Mu'tamad Fi al-Fiqh al-Syafi'i. vol. 1-5. Damsyik: Dar al-Qalam. 